Relations industrielles

Industrial Relations

\title{
Security of the Workman's Family
}

\section{Gérard Tremblay}

Volume 6, numéro 2, mars 1951

URI : https://id.erudit.org/iderudit/1023236ar

DOI : https://doi.org/10.7202/1023236ar

Aller au sommaire du numéro

\section{Éditeur(s)}

Département des relations industrielles de l'Université Laval

ISSN

0034-379X (imprimé)

1703-8138 (numérique)

Découvrir la revue

Citer cet article

Tremblay, G. (1951). Security of the Workman's Family. Relations industrielles / Industrial Relations, 6(2), 34-34. https://doi.org/10.7202/1023236ar

Tous droits réservés @ Département des relations industrielles de l’Université Laval, 1951
Ce document est protégé par la loi sur le droit d'auteur. L'utilisation des services d'Érudit (y compris la reproduction) est assujettie à sa politique d'utilisation que vous pouvez consulter en ligne.

https://apropos.erudit.org/fr/usagers/politique-dutilisation/ 


\section{Security of the Workman's Family}

Our sixth Industrial Relutions Congress will take place next April 23rd and 24th. As usual, its meetings will be held in the large inviting ballroom of the Chateau Frontenac, spacious enough to accommodate from four to five hundred persons.

The theme of the congress, as mentioned above, will be: "Security of the workman's family".

We shall leave intentionally the immediate field of industrial relations to attain a higher level, that of family security which constitutes the most important aspect of social security.

We remember that, in five previous congresses, our studies and discussions focused on the following themes: Industrial relations in Quebec (1946); collective agreement and union security (1947); methods of labourmanagement co-operation (1948); labour relations techniques (1949); wage structure (1950).

The Department of Industrial Relations does not pretend to have exhausted the whole subject of labour-management relations, but is convinced that it has at least pointed out the importance of its numerous aspects.

Social advancement leads us towards other studies, more calm in character, but nevertheless of current importance.

Does this mean that family security has nothing to do with sound labour relations ? Certainly not. On the contrary, it can be, or rather is, in fact, both the cause and the effect thereof.

At a first glance, we notice the constantly expanding scope of collective bargaining which now embraces workmen's security: Guaranteed employment, protection against sickness, invalidity, old age, housing co-operative societies, etc...

The subject of conferences to be given is mentioned hereunder; together, they form a powerful, magnificent and inspiring scheme of initiatives, all tending towards the public weal.

The sittings will give labour, employers' associations, parity committees, government officials, economists and sociologists an opportunity to renew social contacts and to hear most instructive conferences as well as to express their views in popular forums, and collaborate in the building up of a true democratic and Christian society.

The DiRbctor

We are assured that the attendance of this sixth Congress will be as mumerous and interesting as last year's. One can find further information about the Conference in page 63 of the Reolero. 